Jpn. J. Hosp. Pharm.

$\left[\begin{array}{ll}17(5) & 347-352(1991)^{\vdash}\end{array}\right]$

\title{
院内製剤アザチオプリン注射剤の調製とその安定性
}

片桐義博, 馬淵和英, 岩本喜久生

島根医科大学医学部附属病院薬剤部

\section{Preparation and Stability of Azathioprine Injection}

\author{
Yoshihiro Katagiri, KazUhide Mabuchi, and KiKuo Iwamoto \\ Department of Pharmacy, Shimane Medical University Hospital $\dagger$
}

(Received March 14, 1991)

\begin{abstract}
Azathioprine injection was prepared as an immunosuppressive dosage form for organ transplantation. The stability of azathioprine in the injection was investigated under various sterilization and storage conditions. The amount of azathioprine was determined by highperformance liquid chromatography. The amount of azathioprine in the injection decreased slightly after autoclaving but any significant difference was not observed among three sterilization conditions such as $115^{\circ} \mathrm{C}$ for $30 \mathrm{~min}, 121^{\circ} \mathrm{C}$ for $20 \mathrm{~min}$ and $126^{\circ} \mathrm{C}$ for $15 \mathrm{~min}$. Azathioprine in the injection which was autoclaved at $115^{\circ} \mathrm{C}$ for $30 \mathrm{~min}$ was completely stable under subsequent storage at room temperature on exposure to light for 4 weeks. The present azathioprine injection was found to be useful as an immunosuppressive agent for organ transplantation.
\end{abstract}

Keywords - azathioprine; immunosuppressive agent; injection; content; stability; hospital preparation

\section{緒言}

アザチオプリンは, 腎移植後の免疫抑制を目的 として長期投与がなされ，その有効性が認められ ている. 新しい免疫抑制剂としてシクロスポリン が開発され, 臟器移植後の拒絶反応抑制にはシク ロスポリンが用いられることが多くなってきてい る.しかし、シクロスポリンは血中濃度が上㫒し すぎると腎および肝臓障害の発生頻度が高くなる ことが知られている1 $。$ そこで，これらの副作 用を軽減化する目的でアザチオプリンあるいはス テロイド剤を併用し，シクロスポリンの投与量を 極力少なくしようとする試みが，腎移植 ${ }^{4}$ 6) およ び肝移植後 ${ }^{7 ~ 9)}$ の拒絶反応の抑制のために行われ

$†$ 島根県出雲市塩冾町89-1; 89-1, Enya-cho, Izumoshi, 693 Japan
ている.

最近，わが国に执いても新たに幼・小児に対し て生体部分肝移植も行われるようになってきてい る. この生体部分肝移植後の拒絶反応抑制におい ては, 肝毒性の強いシクロスポリンの投与量を減 少させるためアザチオプリンの併用が必要であ り，臨床の場からアザチオプリン注射剤の院内製 剤化が強く要望されている，外国においては，す でにアザチオプリンの注射剤が市販されている が，国内では経口剤のみが市販されている.

今回, 著者らはアザチオプリン注射剂を調製し, オートクレーブによる滅菌時, およびその後の保 存期間中に拉けるアザチオプリンの残存量を測定 し，その安定性について検討した。 


\section{実験方法}

\section{1. 試薬及び使用薬品}

アザチオプリン標品はナカライテスク侏製を, p-アミノ安息香酸は和光純薬製を用いた. 生理食 塩液は局方品（大塚製薬）を, 移動相溶媒は高速 液体クロマトグラフ用試薬（和光純薬）を使用し た. その他の試薬は市販特級品を用いた.

\section{2. $0.2 \%$ アザチオプリン注射郕の調製}

注射剂の調製法はイムラン注射剂（凍結乾燥製 剤）を参考にした ${ }^{10)}$. Table 1 にアザチオプリン 注射剤の製剤処方を示した。アザチオプリン 200 $\mathrm{mg}$ を採り, 生理食塩液 $8 \mathrm{ml}$ に眯濁させ, $1 \mathrm{~N}$ $\mathrm{NaOH} 0.72 \mathrm{ml}$ (アザチオプリンと等モル量)を 添加してアザチオプリンを溶解し, 生理食塩液を 加えて全量 $100 \mathrm{ml}$ とした.この溶液をメンブラン フィルター（マイレクス GV，0.22 $\mathrm{m}$ ) でろ過 し, $5 \mathrm{ml}$ ずつ透明アンプルへ分注した.

\section{3. アザチオプリンの定量}

アザチオプリンの定量は Ding \& Benet $^{11)}$ お よび Lin ら ${ }^{12)}$ の方法を修正した HPLC 法を用い て行った.

\section{1）装置および条件}

装置, 島津 LC-4A 型高速液体クロマトグラ フ ; カラム, Chemcosorb 5-ODS-H (4.6mm i. d. $\times 150 \mathrm{~mm})$; カラム温度, $40^{\circ} \mathrm{C}$; 検出器, 島 津 SPD-2A ; 波長, $325 \mathrm{~nm}$; 記録計, 島津 C-R $2 \mathrm{~A}$; 移動相, $0.01 \mathrm{M}$ 酢酸緩衝液 -メタノール テトラヒドロフラン (92:4:4, pH 4.0); 流速, $1.0 \mathrm{ml} / \mathrm{min} ;$ 検出感度, 0.04 aufs.

2) 検量線

アザチオプリン標品 $200 \mathrm{mg}$ を採り, 生理食塩 液 $8 \mathrm{ml}$ に懸濁させ, $1 \mathrm{~N} \mathrm{NaOH}$ を添加してアザ チオプリンを溶解し, 生理食塩液を加えて全量 100ml とした。この溶液を一定量ずつ採り内部標 準液として $\mathrm{p}-ア ミ ノ$ 安息香酸のメタノール・テト ラヒドロフラン溶夜 $(2 \mathrm{mg} / \mathrm{ml}) 1.6 \mathrm{ml}$ を加え, $0.01 \mathrm{M}$ 酢酸緩衝液（pH 4.0）でアザチオプリン 濃度 $25,50,75,100,125 \mu \mathrm{g} / \mathrm{ml}$ の標準液を作 成した。標準液を HPLC に注入し, 得られたア ザチオプリンのピーク高さから内部標準法により 検量線を作成した。

3）定量操作

$0.2 \%$ ザチオプリン注射剂 $1 \mathrm{ml}$ を採り, 内部 標準液 $1.6 \mathrm{ml}$ を加え，0.01M 酢酸緩衝液で全量 $20 \mathrm{ml}$ とした。この試料溶液 $5 \mu \mathrm{l}$ をHPLCへ注 入し, 検量線よりアザチオプリンの濃度を求め た。

\section{4. 安定性}

調製した $0.2 \%$ アザチオプリン注射剂を局方に 収載されている高圧蒸気法の条件, すなわち $115^{\circ}$ C 30 分, $121^{\circ} \mathrm{C} 20$ 分, $126^{\circ} \mathrm{C} 15$ 分の 3 条件で減 菌し, 滅菌終了直後のアザチオプリンの含量を測 定した。また，0.2\%アザチオプリン注射剤を $115^{\circ} \mathrm{C} 30$ 分の条件下で隇菌した後, 28 日間保存し アザチオプリンの含量を経時的に測定した。保存 条件は室温 $\left(28 \sim 30^{\circ} \mathrm{C}\right) \cdot$ 螢光灯下, 室温 $(28 \sim$ $\left.30^{\circ} \mathrm{C}\right)$ ・遮光下および冷所 $\left(4 \pm 0.5^{\circ} \mathrm{C}\right) \cdot$ 遮光下 の 3 条件とした。 な拉遮光は, 透明アンプルに封 入した注射剤を暗所に保存して行った。

\section{結果}

アザチオプリン標品より作成した検量線をFig. 1 に示した。内部標準物質に対するアザチオプリ ンのピーク高さ比と濃度から回帰直線式を求める と, $\mathrm{Y}=0.00984 \mathrm{X}+0.01955(\mathrm{r}=0.999)$ であり, $25 \sim 125 \mu \mathrm{g} / \mathrm{ml}$ の濃度範囲において, 良好な直線 関係が得られた。また各測定点で変動係数は $1 \%$

Table 1. Formula of $0.2 \%$ Azathioprine Injection

\begin{tabular}{lr}
\hline Rp. Azathioprine & $200 \mathrm{mg}$ \\
1N NaOH & $0.72 \mathrm{ml}$ \\
Normal Saline & ad $100 \mathrm{ml}$ \\
\hline
\end{tabular}




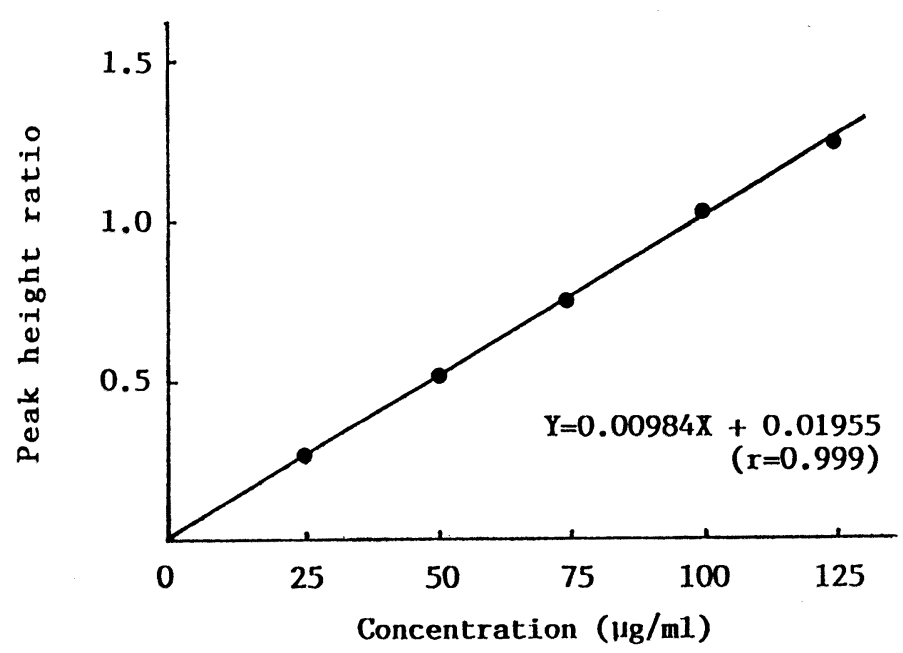

Fig. 1. Calibration Curve for Azathioprine by HPLC

Each point reprensents the mean of 4 determinations.
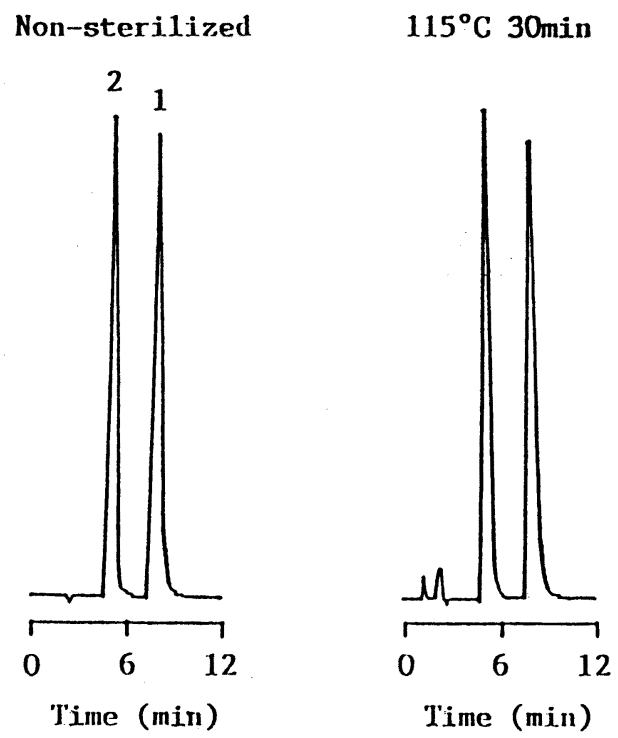

$121^{\circ} \mathrm{C} 20 \mathrm{~min}$

$126^{\circ} \mathrm{C} 15 \mathrm{~min}$

Fig. 2. Chromatograms of Azathioprine Injection before and after Autoclaving Peaks : $1=$ azathioprine; $2=p$-aminobenzoic acid (internal standard).

以下であり, 測定精度も良好であった。

アザチオプリン注射剤の滅菌前と隇菌後のクロ マトグラムをFig. 2 に示した.アザチオプリンお よび内部標準物質である $\mathrm{p}-ア ミ ノ$ 安息香酸は, そ れぞれ保持時間 8.9 分, 5.2 分に溶出し, 単一な ピークとして良好に分離できた。アザチオプリン
のピークは隇菌温度の上䄯とともに僅かずつ低下 し，またそれに伴って滅菌前には見られなかった 分解物に由来すると考えられる 2 つのピークがク ロマトグラム上に認められた。これらのピークは 滅菌温度の上䄯とともに僅かずつ上年する傾向が 認められた.6-メルカプトプリンおよびヒポキサ 
Table 2. Stability of Azathioprine in Alkalinized Saline after Autoclaving

\begin{tabular}{lc}
\hline Condition & $\begin{array}{c}\text { Content of azathioprine } \\
\mathrm{mg} / \mathrm{ml}(8)\end{array}$ \\
\hline Non sterilized & $2.00 \pm 0.01(100.0 \pm 0.1)$ \\
$115^{\circ} \mathrm{C} 30 \mathrm{~min}$ & $1.94 \pm 0.01(97.3 \pm 0.4)$ \\
$121^{\circ} \mathrm{C} 20 \mathrm{~min}$ & $1.92 \pm 0.01(96.2 \pm 0.8)$ \\
$126^{\circ} \mathrm{C} 15 \mathrm{~min}$ & $1.91 \pm 0.02(95.7 \pm 1.3)$ \\
\hline
\end{tabular}

Each value represents the mean \pm S.D. of 5 experiments.

Table 3. Stability of Azathioprine in Alkalinized Saline under Various Storage Conditions

\begin{tabular}{|c|c|c|c|}
\hline \multirow{2}{*}{$\begin{array}{l}\text { Period } \\
\text { (day) }\end{array}$} & \multicolumn{3}{|c|}{ Content of azathioprine } \\
\hline & $\begin{array}{l}\text { Room temperature } \\
\text { under light exposure }\end{array}$ & $\begin{array}{l}\text { Room temperature } \\
\text { under shading }\end{array}$ & $\begin{array}{l}\text { Cold place } \\
\text { under shading }\end{array}$ \\
\hline 0 & $\begin{array}{r}1.94 \pm 0.01 \\
(100.0 \pm 0.4)\end{array}$ & $\begin{array}{r}1.94 \pm 0.01 \\
(100.0 \pm 0.4)\end{array}$ & $\begin{aligned} 1.94 & \pm 0.01 \\
(100.0 & \pm 0.4)\end{aligned}$ \\
\hline 4 & $\begin{aligned} 1.93 & \pm 0.02 \\
(99.4 & \pm 0.9)\end{aligned}$ & $\begin{aligned} 1.94 & \pm 0.02 \\
(100.0 & \pm 1.3)\end{aligned}$ & $\begin{aligned} 1.94 & \pm 0.01 \\
(100.0 & \pm 0.7)\end{aligned}$ \\
\hline 7 & $\begin{aligned} & 1.94 \pm 0.01 \\
&(100.0 \pm 0.7)\end{aligned}$ & $\begin{aligned} 1.95 & \pm 0.02 \\
(100.5 & \pm 1.0)\end{aligned}$ & $\begin{aligned} 1.95 & \pm 0.02 \\
(100.5 & \pm 0.3)\end{aligned}$ \\
\hline 14 & $\begin{aligned} 1.96 & \pm 0.02 \\
(101.0 & \pm 1.0)\end{aligned}$ & $\begin{array}{r}1.93 \pm 0.02 \\
(99.4 \pm 1.8)\end{array}$ & $\begin{aligned} 1.96 & \pm 0.02 \\
(101.0 & \pm 1.2)\end{aligned}$ \\
\hline 21 & $\begin{array}{r}1.95 \pm 0.01 \\
(100.5 \pm 0.6)\end{array}$ & $\begin{array}{r}1.93 \pm 0.02 \\
(99.4 \pm 1.2)\end{array}$ & $\begin{aligned} 1.95 & \pm 0.01 \\
(100.5 & \pm 0.9)\end{aligned}$ \\
\hline 28 & $\begin{aligned} 1.97 & \pm 0.01 \\
(101.5 & \pm 0.6)\end{aligned}$ & $\begin{aligned} 1.96 & \pm 0.02 \\
(101.0 & \pm 1.0)\end{aligned}$ & $\begin{aligned} & 1.94 \pm 0.03 \\
&(100.0 \pm 1.5)\end{aligned}$ \\
\hline
\end{tabular}

Each value represents the mean \pm S.D. of 5 experiments.

ンチンの標品を用いて同定を試みた。これら $2 つ$ のピークのらち，保持時間 2.4 分のピークは6-メ ルカプトプリン標品の保持時間と一致した. ヒポ キサンチン標品はこの HPLC 条件では検出され ず，他のピークについては同定はできなかった。

Table 2 に滅菌前および隇菌終了直後の注射剂 中のアザチオプリンの含量 (残存率) を示した. $115^{\circ} \mathrm{C} 30$ 分, $121^{\circ} \mathrm{C} 20$ 分, $126^{\circ} \mathrm{C} 15$ 分の各条件 下で滅菌を行った場合のアザチオプリンの含量 は, 滅菌前に比べていずれの滅菌条件下でも僅か に低下した。しかし, 各隇菌条件間では差は認め られなかった。

$0.2 \%$ ザチオプリン注射剤を $115^{\circ} \mathrm{C} 30$ 分の条
件下で隇菌した後, 各種条件下において保存した 場合のアザチオプリンの含量（残存率）をTable 3 に示した. 滅菌後28日間まで, いずれの保存条 件下においてもアザチオプリンの含量の低下はま ったく認められず，安定であった.

\section{考察}

アザチオプリンは臓器移植時の免疫抑制療法に おいては，主にシクロスポリンと併用して用いら れることが多い4 9). 本院においては, わが国で 初めて幼児の生体部分肝移植が行われた。 その際 に医師側から，アザチオプリンの経口投与が不可 能であること,さらにその投与量の厳密な調節が 
必要であることにより，アザチオプリン注射剤が 要望された。

アザチオプリンは注射剂としては国内において 市販されていないので, 必要時には院内製剤とし て調製しなければならない，注射剤を調製するに あたっては，その無菌性拉よび安定性等に関する 品質の確保が第一に必要である. 今回, 著者らは アザチオプリン注射剤の院内製剂化を目的とし， 隇菌時および保存時のアザチオプリンの安定性に ついて検討を行った。

アザチオプリンはアルカリ性領域において分解 物として，6-メルカプトプリン，ヒポキサンチン および1ーメチル-4-ニトロ-5-ヒドロキシイミダゾ 一ルを生成することが知られている13,14). 著者ら が行ったいずれの滅菌条件においても，クロマト

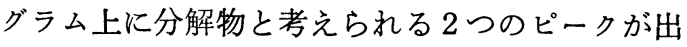

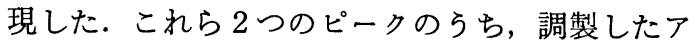
ザチオプリン注射剂の $\mathrm{pH}$ は約 9.6 であり，しか も標品の保持時間と一致したことから, $1 つ\left(t_{R}\right.$ $=2.4$ 分）は6-メルカプトプリンであると考えら れる. 他のピークについては, 1-メチル-4-ニト ロー5-ヒドロキシイミダゾールと考えられるが同 定はできなかった．これらの 2 つの分解物の毒性 について，6-メルカプトプリンはアザチオプリン の活性型薬物であり，アザチオプリンは体内で6メルカプトプリンに変換されて作用するのでまっ たく問題はない，他の 1 つにつては生成量はご く微量であり，また隇菌後のアザチオプリンの残 存率は96〜97\%であることから，この注射剤の安 全性については臨床上ほぼ問題はないと考えられ る.

アザチオプリンの水溶液中での安定性について の報告は少ない. Fell ら13) はアザチオプリン (0.1\%)の生理食塩液を室内散光 $\cdot 85^{\circ} \mathrm{C}$ の条件下 で保存した場合， 5 時間後のアザチオプリン残存 率は約 $93 \%$ であったと報告している。しかし，ア ザチオプリン注射阂の高圧蒸気隇菌時における安 定性については検討されていない，今回調製した アザチオプリン注射剤を局方に収載されている条 件下で高圧蒸気隇菌を行ったところ，アザチオプ リンの含量は僅かに低下する傾向が認められた。
しかし，注射剤中におけるアザチオプリンの含量 の低下は僅かであり， ほぼ安定であった。

アザチオプリン注射剤の保存中における安定性 について, Fell ら ${ }^{13)}$ は生理食塩液中に溶解した場 合, 室温・散光下で 5 時間後においてもアザチオ プリンの分解は認められなかったと報告してい る. 今回調製したアザチオプリン注射剤を $115^{\circ} \mathrm{C}$ 30分の条件下で隇菌した後, 室温・螢光灯下で保 存した場合でも約 1 カ月までは含量の低下がまっ たく認められず，この注射剤は安定な製剤である といえる。なお， $115^{\circ} \mathrm{C} 30$ 分の隇菌条件による無 菌性は，枯草菌による生物学的インジケータによ り随時確認しており，調製したアザチオプリン注 射羭の無菌性は確保されているものと考えられ る.

以上のことから，調製したアザチオプリン注射 剂は局方の条件下で高圧蒸気法による隇菌が可能 であり，また保存期間中の安定性も良好であり， 本製剤は院内製剤として十分使用できるものと考 えられる。

\section{文献}

1) G. B. G. Klintmalm, S. Iwatsuki and T.E. Starzl, Lancet, 2, 470-471 (1981).

2) K.Atkinson, J.C. Biggs, J.Hayes, M. Ralston, A. J. Dodds, A. J. Concannon and D. Naidoo, Br. J. Haematol., 54, 59-67 (1983).

3) M. I. Lorber, C.T. Van Buren, S. M. Flechner, C. Williams and B.D. Kahan, Transplant. Proc., 19, 1808-1810 (1987).

4) M.I. Lorber, S.M.Flechner, C.T. Van Buren, R.H. Kerman and B.D. Kahan, Transplant. Proc., 17(Suppl. 1), 282-285 (1985).

5）吉村了勇, 岡 隆宏, 大森吉弘, 相川一郎, 福田 雅武, 安村忠樹, 荒川幸平, 李 哲柱, 大坂芳夫, 移植, 23, 599-605 (1988).

6) D. Landsberg, A. Rae, A. Chiu, R. Werb, P. Taylor, C.Chan-Yan and A.D. Manson, Transplant. Proc., 21, 3323-3324 (1989).

7) J. Gugenheim, D. Samuel, F. Saliba, D.Castaing and H. Bismuth, Transplant. Proc., 19, 3805-3807 (1987).

8) M. Kalayoglu, R. J. Stratta, R. M. Hoffmann, H. W. Sollinger and F.O. Belzer, Transplant. Proc., 20(Suppl. 1), 524-529 (1988). 
9) O.T. Terpstra, S.W. Schalm, W. Weimar, P.J.A. Willemse, D. Baumgartner, T.H.N. Groenland, F. W. J. Ten Kate, R. J.Porte, S. De Rave, C.B. Reuvers, J. Stibbe and J.L. Terpstra, N. Engl. J. Med., 319, 1507-1511 (1988).

10) E. R. Barnhart, "PHYSICIANS' DESK REFERENCE 44ed.", 1990, p.777.

11) T.L. Ding \& L.Z. Benet, J. Chromatogr.,
163, 281-288 (1979).

12) S. Lin, K. Jessup, M. Floyd, T.F. Wang, C. T. Van Buren, R. M. Caprioli and B.D. Kahan, Transplantation, 29, 290-294 (1980).

13) A.F. Fell, S. M. Plag and J.M. Neil, J. Chromatogr., 186, 691-704 (1979).

14) R. L. Gupta, M. Kumar, R.K. Singla and S. Singh, Indian J. Pharm. Sci., 49, 169-171 (1987). 